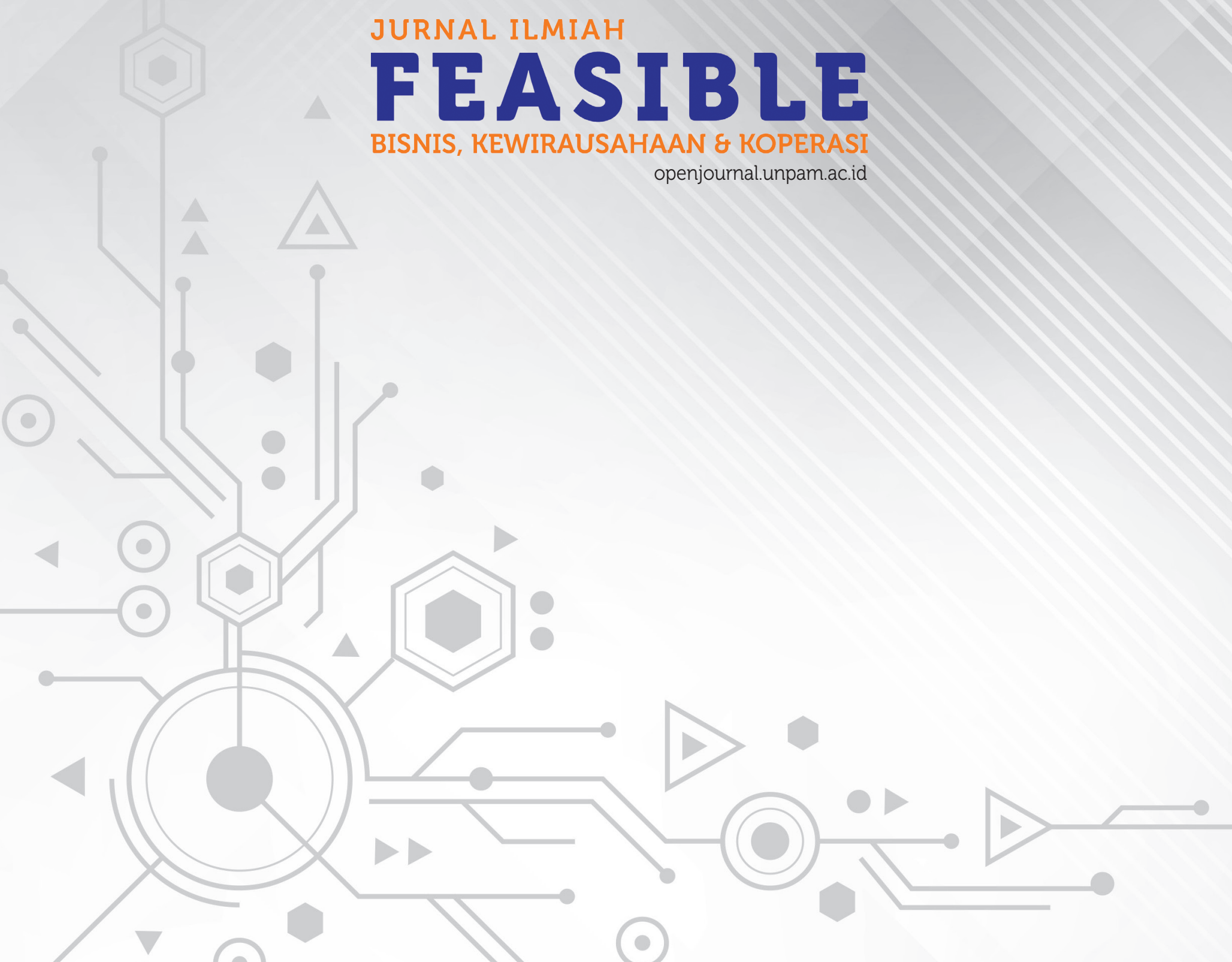




\title{
ANALISIS BAURAN PEMASARAN DALAM MENINGKATKAN VOLUME PENJUALAN AZKA TOYS PAMULANG TANGERANG SELATAN
}

\author{
Aidil Amin Effendy \\ Fakultas Ekonomi, Universitas Pamulang \\ aidilamineffendy@gmail.com
}

\begin{abstract}
Abstrak
Tujuan dari penelitian ini adalah untuk mengetahui implementasi strategi bauran pemasaran Azka Toys Pamulang Tangerang Selatan dan mengetahui implementasi strategi bauran pemasaran Azka Toys Pamulang Tangerang Selatan dalam meningkatkan penjualan. Pada penelitian ini, pendekatan penelitian yang digunakan adalah menggunakan metode kualitatif. Penelitian kualitatif bertujuan untuk mendapatkan pemahaman yang mendalam mengenai situasi yang dihadapi. Dalam penelitian ini, peneliti bertindak sebagai instrumen kunci, partisipan penuh sekaligus pengumpul data, sedangkan instrumen yang lain sebagai penunjang dan teknik pengumpulan data yangdigunakan pada metode kualitatif adalah interview (wawancara), observasi, dan dokumentasi. Adapun hasil penelitian yang diperoleh, secara umum produk Azka Toys Ular Tangga Sholat dan Baitul Maal ini mengalami perkembangan penjualan yang baik dari tahun ke tahun jika diakumulasi kedua produk yang dihasilkan oleh Azka Toys, dimana pada tahun 2018 terjadi peningkatan volume penjualan yang sangat signifikan. Dari peningkatan volume penjualan tersebut didapat rata-rata jumlah penjualan Azka Toys Ular Tangga Sholat Pamulang Tangerang Selatan dari tahun 20142018 adalah sebesar 1.020,4 unit, dengan penjualan terbesar pada tahun 2018 yaitu sebesar 1.303 produk mainan Islami Edukatif Azka Toys. Keberhasilan peningkatan volume penjualan Azka Toys diperoleh dari penerapan strategi bauran pemasaran yang dikenal dengan $4 P$, adapun bauran pemasaran tersebut meliputi produk, harga, promosi dan tempat.
\end{abstract}

Kata kunci: Bauran Pemaran,Volume Penjulan

\begin{abstract}
The purpose of this study was to determine the implementation of the marketing mix strategy Azka Toys Pamulang South Tangerang and find out the implementation of the marketing mix strategy Azka Toys Pamulang South Tangerang in increasing sales. In this study, the research approach used is to use qualitative methods. Qualitative research aims to gain a deep understanding of the situation at hand. In this study, researchers acted as key instruments, full participants as well as data collectors, while other instruments as support and data collection techniques used in qualitative methods were interviews, observation, and documentation. The results of the research obtained, in general, the products of Azka Toys Snake Ladder Prayer and Baitul Maal experienced good sales growth from year to year if the two products were accumulated by Azka Toys, where in 2018 there was a significant increase in sales volume. From the increase in sales volume, the average number of sales of Azka Toys Snake obtained from the South Tangerang Pamulang Prayer Ladder from 20142018 was 1,020.4 units, with the largest sales in 2018 which was 1,303 Educational Islamic toys Azka Toys. The success of increasing sales volume of Azka Toys is obtained from the application of a marketing mix strategy known as $4 P$, while the marketing mix includes products, prices, promotions and places.
\end{abstract}

Keyword: Marketing Mix, Sales Volume 


\section{PENDAHULUAN \\ Latar Belakang Masalah}

Pada era modern saat ini, persaingan usaha sangatlah kompetitif dengan berbagai strategi pemasaran baik dari strategi produk, harga, lokasi maupun dari segi pemasaran dalam memenangi persaingan, bahkan tidak sedikit perusahaan yang menerapkan produknya dengan bentuk inovasi dan kreatif guna memenangi persaingan dan suatu perusahaan selalu menginginkan agar hasil penjualannya meningkat secara terus-menerus. Usaha dalam meningkatkan penjualan ini sangat diperlukan bagi keberlangsungan perusahaan.

Strategi pemasaran efektif dan efisien harus konsisten dilakukan agar perusahaan tidak mengalami kerugian sehingga berdampak pada penurunan volume penjualan dan tidak mampu bersaing dengan perusahaan sejenis lainnya. Jika perusahaan tidak mampu bersaing dengan perusahaan sejenis lainnya, maka dipastikan perusahaan akan mengalami kebangkrutan. Misalnya, ketika pesaing usaha terus berinovasi dan menciptakan produk yang diferensiasi serta dibutuhkan masyarakat, maka perusahaan kita akan semakin tertinggal dengan perusahaan pesaing. Maka, perusahaan harus bisa mengenal dan mengadakan produk sesuai dengan selera dan kebutuhan konsumen, mendesain produk dengan inovasi dan kreatif serta menawarkan harga yang kompetitif. Bahkan perusahaan harus dapat menciptakan produk dengan mempunyai cirri khas yang dapat mudah dikenal oleh masyarakat untuk meningkatkan volume penjualan.

Perusahaan terbaik adalah yang dapat menerapkan pemasaran terbaik dengan disesuaikan menurut kebutuhan konsumen ataupun pesaing guna bersaing dengan perusahaan sejenis lainnya. Persaingan produk yang kompetitif menyebabkan adanya strategi pemasaran yang berguna dalam mengembangkan usahanya agar mampu mempertahankan eksistensinya sebagai perusahaan berdaya saing dan kompetitif. Agar mampu bersaing, perusahaan harus mempunyai nilai lebih untuk memuaskan daya beli konsumen. Strategi pemasaran harus dirancang secara efektif dan efisien, mulai dari menganalisis kekuatan dan kelemahan usaha pesaing. Dengan begitu perusahaan dapat mengetahui peluang untuk dapat bersaing dengan perusahaan pesaing. Kegiatan pemasaran pada dasarnya berfokus pada produk, penetapan harga, pemilihan tempat dan strategi promosi sebagai bauran pemasaran. Strategi bauran pemasaran memegang peranan penting bagi kelangsungan bisnis usaha.
Perusahaan dikatakan berhasil dan sukses dalam bersaing dengan perusahaan sejenis lainnya, jika perusahaan dapat menerapkan strategi bauran pemasaran secara efektif dan dapat dibuktikan dengan tingkat penjualan yang signifikan dalam suatu periode tertentu. Pada umumnya apabila volume penjualan yang diperoleh rendah maka bisa dikatakan keuntungan yang diperoleh pun akan rendah juga. Dalam Strategi pemasaran perlunya memperhatikan produk yang dihasilkan secara berkualitas karena akan mempengaruhi tingkat penjualan. Harga yang ditawarkan kepada konsumen juga harus terjangkau atau sesuai selera dan kebutuhan yang diharapkan oleh konsumen sehingga akan meningkatkan penjualan. Lokasi usaha dan saluran distribusi juga harus terjangkau dan strategis, sehingga memudahkan konsumen untuk datang dalam membeli produk perusahaan kita. Dari keberhasilan dalam peranan marketing mix atau bauran pemasaran untuuk meningkatkan penjualan yang diharapkan perusahaan, maka perusahaan harus efektif dan efisien dalam menerapkan strategi pemasaran atau bauran pemasaran.

Dalam Manajemen pemasaran, bauran pemasaran (marketing mix) merupakan faktorfaktor penting yang diperlukan perusahaan untuk menghasilkan pangsa pasar yang konsisten sesuai dengan harapan perusahaan. Adapun Bauran pemasaran terdiri dari empat item yang disebut sebagai "empat P", yaitu: produk (product), harga (price), promosi (promotion), tempat (place).

Dalam era kompetitif, bauran pemasaran atau strategi pemasaran harus diterapkan perusahaan agar dapat menghasilkan laba yang diperoleh secara maksimal. Maka, salah satu usaha yang penuh potensial yaitu produk yang mempunyai pangsa pasar yang jelas dan terarah, seperti produk mainan edukatif sebagai media pembelajaran, dimana pangsa pasarnya adalah anak-anak dan orangtua atau pada sebuah sekolah. Namun yang perlu diketahui saat ini permainan edukatif untuk anak dalam bentuk cetakan sudah tersaingi oleh permainan berbasis digital dan teknologi, membuat sebagian besar seorang anak menghabiskan waktunya dengan bermain gadget, play station, bahkan ada sebagian anak yang sudah memiliki facebook, instagram dan lain sebagainya. Hal ini mengakibatkan anak sudah malas untuk belajar terutama belajar mengenai materi agama.

Hal tersebut membuat semangat Azka Toys dalam membuat sebuah permainan Islami Edukatif yang kreatif dan inovatif serta menyenangkan anak dalam bermain. Sehingga 
anak secara tidak langsung anak akan senang belajar mengenai materi agama yang selama ini biasanya anak malas untuk belajar, dengan hadirnya produk Azka Toys, diantaranya berupa Baitul Maal dan Ular Tangga Sholat, anak akan lebih mudah mempelajarinya karena dalam bentuk permainan.

Secara umum, Baitul Maal adalah sebuah permainan islami edukatif yang melibatkan kognitif dan motorik anak yang lebih dikenal dengan Monopoli, namun Monopoli ini diinovasikan secara islami agar anak dapat belajar materi-materi agama melalui sebuah permainan Baitul Maal, seperti hafalan surat, doa-doa sehari-hari, rukun Islam dan materi agama lainnya. Dalam baitul maal juga diajarkan materi berwirausaha sesuai dengan syariat agama Islam dan diajarkan oleh Nabi Muhammad SAW.

Adapun permainan Ular Tangga Sholat, seperti halnya Ular Tangga lainnya namun Ular Tangga Sholat ini menyajikan gambar pada papan permainan Ular Tangga dengan gambar-gambar yang menunjang anak untuk belajar tentang sholat, dilengkapi dengan kartu "Al Qur'an dan Hadits" mengenai sholat serta kartu hafalan bacaan-bacaan sholat. Dengan hadirnya Ular Tangga Sholat ini diharapakan anak dapat belajar sholat dengan cara yang menyenangkan yang berlandaskan dari wasiat Nabi Muhammad yaitu Kitab Al Qur'an dan Hadits Nabi serta termotivasi untuk melakukan sholat 5 waktu secara konsisten.

Dalam usahanya, Azka Toys selalu mengembangkan strategi pemasaran melalui bauran pemasaran yaitu strategi Produk, Harga, Promosi dan Lokasi (Tempat). Maka dapat disimpulkan dari permasalahan yang terjadi dalam sebuah pemasaran pada Azka Toys, maka dengan adanya permasalahan terkait pemasaran produk Usaha Azka Toys yang terletak di Pamulang Tangerang Selatan, Azka Toys perlu menemukan strategi yang efektif dalam meningkatkan volume penjualan guna bersaing dengan perusahaan sejenis lainnya.

Penjualan yaitu sebuah usaha dalam mengenalkan produk kepada orang lain dan mempengaruhi seseorang untuk mengajak orang lain membeli barang atau jasa yang kita ditawarkan. Adapun volume penjualan adalah besarnya jumlah barang atau jasa yang terjual pada saat periode tertentu. Semakin besarnya total produk atau jasa yang terjual, maka semakin besar juga kemungkinan laba yang dapat dihasilkan perusahaan.

Saat perusahaan terus menerus dapat membuat sebuah inovasi dan diferensiasi dalam bauran pemasaran yang dikenal dengan “empat P",yaitu: produk (product), harga (price), promosi (promotion), tempat (tempat) dalam meningkatkan volume penjualan, maka perusahaan dapat mampu bersaing dengan perusahaan sejenis lainnya dan dapat mengembangkan perusahaannya menjadi perusahaan internasional bahkan perusahaan multinasional. Oleh karena itu, peneliti tertarik untuk membuat sebuah penelitian yang berjudul: "Analisis Bauran Pemasaran dalam Meningkatkan Volume Penjualan (Studi Kasus Azka Toys Pamulang Tangerang Selatan)”.

\section{Perumusan Masalah}

Berdasarkan latar belakang masalah di atas maka dapat dirumuskan Perumusan Masalah sebagai berikut:

1. Bagaimana Azka Toys dalam mengimplementasikan strategi bauran pemasaran?

2. Bagaimana Azka Toys dalam mengimplementasikan strategi bauran pemasaran untuk meningkatkan volume penjualan?

\section{Tujuan Penelitian}

1. Mengetahui implementasi strategi bauran pemasaran Azka ToysPamulang Tangerang Selatan.

2. Mengetahui implementasi strategi bauran pemasaran Azka Toys Pamulang Tangerang Selatan dalam meningkatkan volume penjualan.

\section{Manfaat Penelitian}

\section{Secara Teoritis}

Dalam Penelitian ini diharapkan dapat dijadikan sebagai sumber dan pedoman keilmuan bagi masyarakat mengenai solusi dalam mengatasi permasalahan pemasaran dan penurunan volume penjualan, terutama dalam penjualan produksi mainan. Dan juga sebagai acuan untuk meningkatkan pendapatan hasil usaha terutama dalam mainan dan sebagai pelajaran yang dapat diambil saat terjadi kendala dalam turunya tingkat pendapatan dan volume penjualan

\section{Secara Praktis}

a. Untuk Perusahaan

Dalam Penelitian ini semoga dapat memberikan saran, ide, gagasan dan masukan kepada sebuah perusahaan agar dapat lebih meningkatkan volume penjualannya dan mampu bersaing dengan perusahaan sejenis lainnya melalui sebuah strategi $4 \mathrm{P}$ yaitu produk (product), harga (price), promosi (promotion), tempat (place).

b. Untuk Masyarakat Semoga Penelitian ini juga sebagai 
pedoman bagi masyarakat dalam mengatasi kendala terkait pemasaran dan penjualan serta memberikan ide dan gagasan bagi masyarakat agar dapat mengetahui cara terbaik dalam memasarkan produk atau jasanya melalui strategi bauran pemasaran dalam meningkatkankan penjualan sehingga timbulnya masyarakat yang sejahtera.

c. Untuk Penulis

Penelitian ini diharapakan sebagai acuan untuk penelitian selanjutnya, juga diharapkan dapat menambah keilmuan terkait pengetahuan bauran pemasaran, penjualan dan dapat menambah wawasan serta pengalaman baru mengenai keilmuan terkait penelitian.

d. Untuk penelitian selanjutnya

Penelitian ini juga diharapkan sebagai acuan bagi peneliti selanjutnya dalam meneliti, dan pedoman jika penelitiannya mengenai strategi bauran pemasaran dan penjualan.

\section{Landasan teori}

\section{Pengertian Pemasaran}

Dalam bahasa Inggris, istilah pemasaran dikenal dengan nama marketing. Marketing merupakan proses di mana seseorang atau kelompok dapat memenuhi need dan want melalui penciptaan, penawaran dan pertukaran barang dan jasa.

Adapun Pemasaran adalah salah satu kegiatan utama yang perlu dilakukan oleh perusahaan baik itu perusahaan produk ataupun jasa dalam upaya untuk mempertahankan eksistensi usahanya. Hal tersebut disebakan karena sebuah pemasaran merupakan salah satu kegiatan utama perusahaan, dimana pemasaran secara langsung berhubungan dengan pangsa pasar ataupun konsumen. Maka kegiatan pemasaran dapat dikatakan sebagai kegiatan manusia yang berlangsung dalam kaitannya dengan pasar.

Mengenai arti Pemasaran yaitu sebuah proses sosial dan manajerial yang dilakukan individu dan kelompok untuk memperoleh apa yang mereka perlukan dan inginkan dengan menciptakan, menawarkan, dan saling membeli produk yang memiliki nilai dengan pihak lainnya. Menurut Kotler dan Armstrong, pemasaran adalah proses dimana perusahaan harus menciptakan nilai bagi pelanggan dan membangun hubungan yang signifikan dengan pelanggan dengan tujuan untuk mendapatkan nilai lebih dari konsumen. Dalam kegiatan memasarkan produk tidak hanya menawarkan produk ataupun jasa saja dalam menjual barang kepada konsumen akan tetapi juga mencakup kegiatan yang lebih luas lagi yaitu seperti menjual, membeli, mengangkut, mensortir, menyimpan dan lain sebagainya.

Dari beberapa definisi diatas, maka dapat ditarik kesimpulan bahwa pemasaran merupakan sebuah usaha yang dilakukan perusahaan dalam menggabungkan rencana-rencana strategis dan efektif yang bertujuan sesuai dengan selera dan kebutuhan konsumen untuk memperoleh keuntungan yang diharapkan perusahan. Oleh karena itu, definisi pemasaran lebih diidentikan sebagai proses pengenalan produk atau servis kepada konsumen yang potensial. Aspek-aspek pemasaran ini dapat meliputi antara lain periklanan, public relation, promosi dan penjualan.

Dalam perusahaan, tujuan utama pemasaran adalah untuk memaksimalkan keuntungan dengan membuat strategi penjualan.

Dalam Kegiatan pemasaran perusahaan perlu memberikan pelayanan terbaik kepada konsumen bila ingin mandapatkan respon baik dari konsumen. Perusahaan harus secara penuh bertanggung jawab mengenai kepuasan produk yang ditawarkan tersebut. Dengan demikian, maka segala kegiatan perusahaan, harusnya diarahkan untuk dapat memahami selera dan kebutuhan konsumen yang pada akhirnya bertujuan untuk memperoleh keuntungan yang maksimal.

\section{Konsep Pemasaran}

Dalam konsep pemasaran, bahwasannya pencapaian tujuan perusahaan tergantung kepada seberapa mampu sebuah perusahaan memahami selera dan kebutuhan pasar serta penyampaian kepuasan yang diinginkan itu lebih efektif dan efesien dibandingkan pesaing. Konsep pemasaran dinyatakan dengan cara beragam seperti:

a. Kami mewujudkan keinginan anda;

b. Kami tidak puas sebelum anda puas;

c. Setia melayani anda; dan

d. Memperoleh lebih dari apa yang anda bayarkan.

Pada prinsipnya mengenai konsep pemasaran dan juga konsep penjualan mempunyai pengertian yang berbeda. Konsep penjualan mempunyai perspektif dari dalam keluar. Adapun Konsep itu 
sendiri dimulai dengan produsen, yaitu berfokus pada produk perusahaan yang sudah ada dan melakukan penjualan dan promosi yang efektif untuk memperoleh penjualan yang mampu mendatangkan laba. Sebaliknya konsep pemasaran mempunyai perspektif dari luar ke dalam. Konsep yang memusatkan perhatian penuh pada tercapainya minat pelanggan untuk mendapatkan penjualan jangka pendek.

\section{Strategi Pemasaran}

Dalam pengertian Strategi Menurut Marrus, yaitu sebagai suatu proses penentuan rencana strategis para pemimpin puncak yang berfokus pada tujuan jangka panjang organisasi, disertai penyusunan suatu cara atau upaya bagaimana agar tujuan tersebut dapat dicapai. Perencanaan strategi pemasaran adalah menemukan berbagai peluang yang menarik kemudian menyusun strategi pemasaran yang menguntungkan. Adapun Menurut Chandra, strategi pemasaran merupakan rencana yang menjabarkan ekspektasi perusahaan akan dampak dari berbagai aktivitas atau program pemasaran terhadap permintaan produk atau lini produknya di pasar sasaran tertentu. Strategi pemasaran (marketing strategy) menentukan target pasar dan bauran pemasaran yang terkait. Strategi ini adalah gambaran mengenai apa yang akan dilakukan suatu perusahaan di pasar. Diperlukan dua bagian yang saling berhubungan yaitu:

a. Target pasar, yaitu sekelompok konsumen yang ingin ditarik oleh perusahaan.

b. Bauran pemasaran, yaitu variabel yang akan diawasi yang disusun oleh perusahaan untuk memuaskan kelompok yang ditargetkan perusahaan.

Menurut Kotler dan Keller. (2009) dalam bukunya "Manajemen Pemasaran" menjelaskan bahwa "strategi pemasaran adalah logika pemasaran yang dilaksanakan dengan harapan bahwa unit bisnis akan mencapai sasaran pemasaran". Philip Kotler berpendapat bahwa strategi pemasaran dibagi menjadi 3 bagian, yaitu:

\section{a. Segmenting}

Segmenting Merupakan kegiatan membagi suatu pasar menjadi beberapa kelompok pembeli yang berbeda yang memiliki kebutuhan, karakteristik, atau perilaku yang berbeda yang dimana membutuhkan produk atau bauran pemasaran yang berbeda. Adapun segmentasi pasar yaitu me- ngidentifikasi konsumen dengan kebutuhan dan selera yang sama dan memenuhi kebutuhan-kebutuhan lain dengan menawarkan produk.

Ada 4 variabel dalam segmentasi, yaitu:

1) Segmentasigeografis, merupakan segmentasi yang mengharuskan pembagian pasar menjadi unit geografis seperti Negara, Provinsi, wilayah, kota, atau lingkungan.

2) Segmentasi demografis, merupakan upaya membagi pasar menjadi sejumlah kelompok berdasarkan variabel-variabel seperti usia, gender, ukuran keluarga, siklus hidup keluarga, pendapatan, pekerjaan, pendidikan, agama, ras dan kebangsaan.

3) Segmentasi psikografis, merupakan metode memilah-milah suatu pasar kedalam segmen-segmen nilai dan gaya hidup (value andlifestyle) yang dianut. Dengan asumsi bahwa dalam lingkungan yang homogeny sekalipun, pola aktifitas, konsumsi dan perilaku tiap orang bisa berbeda-beda, tergantung nilai dan gaya hidupnya.

4) Segmentasi perilaku, merupakan upaya membagi kelompok berdasarkan status pemakai, kejadian, tingkat penggunaan, status kesetiaan, tahap kesiapan dan sikap.

b. Targeting

Targeting adalah proses mengevaluasi daya tarik setiap segmen pasar dan memilih satu atau beberapa segmen pasar untuk dimasuki. Secara tradisional, targeting didefinsikan sebagai proses pemilihan pasar tujuan yang tepat untuk produk dan layanan perusahaan, dan mereka mendefinisikan ulang targeting sebagai strategi mendalam pengalokasian sumber daya perusahaan secara efektif karena sumber daya tersebutterbatas sehingga harus dipikirkan cara menyesuaikan kondisi perusahaan dengan segmen pasar tujuan guna mencapai tujuan dan hasil yang sempurna dengan efektif serta efisien.

c. Positioning

Merupakan upaya memposisikan suatu produk agar menduduki tempat yang jelas, dikehendaki dan relatif berbeda terhadap produk pesaing di pemikiran konsumen atau kon- 
sumen sasaran. Saat ini pengertian positioning telah berubah dari strategi menempati pemikiran konsumen dengan penawaran perusahaan menjadi strategi untuk mengarahkan kepercayaan terhadap merk perusahaan.

\section{Pengertian Manajemen Pemasaran}

Pengertian Manajemen pemasaran menurut RW. Suparyanto \& Rosad (2015:3), adalah ilmu yang mempelajari perencanaan, pelaksanaan, dan pengendalian terhadap produk (barang dan jasa), penetapan harga, pelaksanaan distribusi, aktivitas promosi, yang dilakukan oleh orang tertentu, dengan proses tertentu, yang ditunjang dengan bukti fisik untuk menciptakan pertukaran guna memenuhi kebutuhan atau keinginan pelanggan, sehingga mencapai tujuan perusahaan.

\section{Konsep Manajemen Pemasaran}

Menurut RW. Suparyanto dan Rosad (2015:7-9) konsep inti pemasaran dapat diklasifikasikan menjadi lima jenis, antara lain konsep produksi, konsep produk, konsep penjualan, konsep pemasaran, konsep pemasaran berorientasi sosial. Kelima konsep tersebut dapat dijelaskan sebagai berikut:

a. Konsep Produk

Manajer pemasaran yang menganut konsep produk, umumnya memiliki sudut pandang bahwa kualitas produk adalah faktor utama bagi keberhasilan perusahaan dalam pencapaian efektifitas pemasaran. Saat produk menjadi berkualitas dan inovatif, maka semakin menimbulkan ketertarikan konsumen dalam membeli produk atau jasa yang kita tawarkan. Dengan demikian perusahaan harus berupaya menciptakan produk dengan kualitas dan inovatif yang lebih baik dari pada produk pesaing. Bagian pengembangan produk pada sebuah perusahaan berperan sangat penting demi terciptanya produk yang kompetitif. Dalam mengembangkan produk yang berkualitas, perusahaan harus terus menemukan cara yang ampuh dan tiada henti dalam menghasilkan produk berkualitas, dan pemanfaatan teknologi menjadi faktor penentu kesuksesan.

b. Konsep Produksi

Berbeda dengan konsep produk, manajer pemasaran yang berhaluan pada konsep produksi mempunyai pola pikir bahwa pasar sasaran le- bih tertarik terhadap produk yang harganya murah dan relative mudah untuk mendapatkan produk tersebut. Dengan demikian pelaku bisnis akan menekan biaya produksi seefisien mungkin. Demikian juga biaya distribusi yang dikeluarkan untuk mengirimkan produk sampai ke pasar sasaran akan diupayakan secara efisien.

c. Konsep Penjualan

Manajer pemasaran yang berhaluan konsep penjualan mempunyai pola pikir bahwa pasar sasaran tidak akan membeli produk perusahaan secara cepat dan dalam jumlah banyak jika tidak dibujuk dengan berbagai program penjualan. Dengan demikian pemasar akan melakukan berbagai propaganda agar pasar sasaran mau membeli produk tersebut. Pemasar berpendapat bahwa keuntungan yang besar akan diperoleh dengan cara mencapai omzet penjualan yang besar pula.

d. Konsep Pemasaran

Manajer pemasaran akan memperhatikan kebutuhan atau keinginan pasar sasaran, lalu menawarkan produk sesuai dengan kebutuhan atau keinginan pasar sasaran tersebut, serta membedakannya dari produk pesaing. Produk yang laku diperjualbelikan adalah produk yang dibutuhkan atau diinginkan oleh pasar sasaran. Manajer pemasaran akan mengintegrasikan unsur-unsur bauran pemasaran. Manajer pemasaran berpendapat bahwa semua keuntungan dan kesinambungan usaha akan diperoleh perusahaan apabila berhasil memberikan kepuasaan kepada pasar sasaran. Jika pasar sasaran memperoleh kepuasan, mereka akan menjadi pelanggan yang loyal. Jika pelanggan sudah loyal, mereka akan melakukan pembelian ulang produk perusahaan secara rutin, lebih sering, dalam jumlah yang besar, tidak berpengaruh oleh produk pesaing, serta menyampaikan berita baik kepada orang lain dengan penuh kesadarn sekaligus mengajaknya untuk turut mengkonsumsi produk perusahaan.

e. Konsep Pemasaran Berorientasi Sosial Pada dasarnya konsep ini memilki kemiripan dengan konsep pemasaran. Kelebihannya konsep ini perusahaan 
turut memperhatikan dan meningkatkan kesejahteraan masyarakat, dan lingkungan. Perusahaan memperhatikan keseimbangan antara kepentingan intern dan ekstern. Jadi bukan hanya perusahaan yang memperoleh keuntungan dan kesinambungan usaha tetapi anggota masyarakat dan lingkungan juga turut menerima manfaatnya.

\section{Bauran Pemasaran}

Dalam Manajemen pemasaran dikelompokkan dalam 4 (empat) aspek yang sering dikenal dengan marketing mix atau bauran pemasaran. Menurut Kotler dan Armstrong, bauran pemasaran (marketing mix) adalah kumpulan alat pemasaran taktis terkendali yang dipadukan perusahaan untuk menghasilkan respon yang diinginkannya di pasar sasaran. Bauran pemasaran terdiri dari empat kelompok variabel yang disebut "empat P",yaitu:

a. Product/Produk.

Produk yaitu sebuah barang atau jasa yang ditawarkan perusahaan kepada pasar pangsa pasarnya. Jenis-jenis yang termasuk dalam bauran produk antara lain ragam produk, kualitas, design, fitur, nama merek, kemasan, serta layanan.

b. Price/Harga.

Harga merupakan jumlah uang yang harus dibayarkan konsumen untuk memperoleh produk atau jasa yang diinginkan. Harga adalah satu-satunya unsur bauran pemasaran yang menghasilkan pendapatan, sedangkan elemen lainnya menghasilkan biaya. Adapun Harga adalah jenis bauran pemasaran yang paling mudah disesuaikan dengan kemampuan konsumen dan membutuhkan waktu yang relatif singkat dalam mengubahnya, sedangkan ciri-ciri produk, saluran distribusi, bahkan promosi membutuhkan lebih banyak waktu.

c. Place/Tempat.

Tempat atau saluran pemasaran yaitu meliputi aktivitas perusahaan yang membuat produk atau jasa yang diperuntukkan bagi pelanggan sasaran. Saluran distribusi adalah rangkaian organisasi yang saling berkaitan dalam proses untuk menjadikan suatu produk atau jasa siap untuk digunakan atau dikonsumsi. Saluran distribusi dapat diartikan sebagai himpunan perusahaan dan perorangan yang mem- bantu dalam pengalihan hak atas barang atau jasa tertentu selama barang atau jasa tersebut berpindah dari produsen atau pedagang ke konsumen.

d. Promotion/Promosi.

Promosi berarti suatu kegiatan dalam menyampaikan produk dan mengajak pelanggan untuk membeli produk atau jasa tersebut. Definisi promosi menurut Kotler adalah berbagai kegiatan yang dilakukan oleh produsen untuk mengomunikasikan manfaat dari produknya, membujuk, dan mengingatkan para konsumen sasaran agar membeli produk tersebut. Secara rinci tujuan promosi menurut Tjiptono adalah menginformasikan, mengajak pelanggan sasaran dan mengingatkan. Bagi produsen, promosi adalah kegiatan untuk menginformasikan produk, mengajak konsumen untuk membeli serta mengingatkan konsumen agar tidak melupakan produk, sedangkan bagi konsumen, promosi adalah komunikasi antara produsen atau pedagang dan konsumen.

\section{Analisis SWOT}

Dalam Analisis SWOT yaitu merupakan singkatan dari strengths (kekuatan), weaknesses (kelemahan), oportunities (peluang), dan threats (ancaman), merupakan suatu metode penyusunan strategi tebaik dan efektif perusahaan atau organisasi. Kotler dan Keller membagi analisis SWOT ke dalam dua faktor, yaitu faktor eksternal yang terdiri dari peluang dan ancaman dan adapun dari faktor internal yang terdiri dari kekuatan dan kelemahan. Analisis SWOT adalah pengidentifikasian beberapa faktor secara sistematis dan terarah untuk merumuskan strategi yang akan dipergunakan perusahaan. Sastradipoera juga menjelaskan bahwa analisis SWOT merupakan salah satu metode yang populer untuk menetapkan strategi manajemen pemasaran yang efektif dan efisien. Analisis SWOT akan memasangkan ke 4 (empat) faktor yang saling berhubungan sehingga diperoleh hasil berupa beberapa rencana yang digunakan sebagai strategi alternatif perusahaan dalam memenangi persaingan dengan perusahaan sejenis lainnya.

\section{Pengertian Volume Penjualan}

Pengertian Penjualan adalah ilmu dan seni mempengaruhi dan membujuk pribadi atau seseorang yang dilakukan oleh penjual untuk mengajak orang lain 
membeli barang atau jasa yang ditawarkan. Sedangkan, volume penjualan adalah banyaknya barang atau jasa yang terjual pada saat terjadi tukar-menukar. Semakin besar jumlah barang atau jasa yang terjual, semakin besar pula kemungkinan keuntungan yang dihasilkan perusahaan.

Adapun Penjualan Menurut Swastha adalah sebagai Ilmu dan seni yang mempengaruhi pribadi yang dilakukan oleh penjualan untuk mengajak orang lain agar membeli barang atau jasa yang ditawarkan. Menurut Stanton menyatakan bahwa menjual merupakan aktivitas atau kegiatan yang dapat menguntungkan apabila rencana atau bagian dari menjual tersebut sudah menjadi aksi. Volume penjualan mempunyai arti penting dalam kegiatan yang dilakukan secara efektif oleh penjualan untuk mendorong agar konsumen mau membeli. Tujuan dari volume penjualan yaitu untuk memperkirakan seberapa besar keuntungan yang diterima dengan menjual produk kepada konsumen serta biaya yang telah dikeluarkan. Naik turunnya volume penjualan perusahaan dapat dilihat dari intesitas pembelian konsumen dan area perusahaan. Adapun indikator dari volume penjualan menurut Kotler yaitu harga, promosi, saluran distribusi, dan produk. Berdasarkan indikator tersebut maka strategi bauran pemasaran diperlukan dalam meningkatkan volume penjualan.

Mengenai Volume penjualan dalam penelitian ini adalah jumlah hasil penjualan produk permainan anak edukasi yang terjual pada Azka Toys Pamulang Tangerang Selatan.

\section{Pengertian Operasional}

Yang dimaksud dengan "Analisis Bauran Pemasaran dalam Meningkatkan Volume Penjualan Azka Toys (Studi Kasus Azka Toys Pamulang Tangerang Selatan)", dalam penelitian ini adalah bagaimana analisis strategi bauran pemasaran dalam implementasi peningkatan volume penjualan Azka ToysPamulang Tangerang Selatan.

\section{METODOLOGI \\ Lokasi Penelitian}

Lokasi penelitian merupakan suatu sumber untuk mendapatkan data yang dibutuhkan mengenai masalah yang akan diteliti. Penelitian ini dilakukan pada produsen permainan anak Islami edukatif yang kantornya terletak di Perumahan Bamboo Prime Residence, blok D.20,
Jl. Lele Raya no.6, Bambu Apus pamulang Tangerang Selatan.

\section{Pendekatan Penelitian}

Pada Penelitian ini, Pendekatan penelitian yang digunakan adalah menggunakan metode kualitatif. Penelitian kualitatif bertujuan untuk mendapatkan pemahaman yang mendalam mengenai situasi yang dihadapi (Cooper dan Schindler, 2006). Penelitian kualitatif memberikan gambaran mengenai objek yang akan diteliti.

MenurutNanaSyaodihSukmadinata(2007: 60-62), penelitian yang menggunakan pendekatan kualitatif dalam sebuah metodologi penelitian yaitu mempunyai karakteristik-karakteristik sebagai berikut : (a) berpijak pada konsep naturalistik, (b) kenyataan berdimensi jamak, kesatuan utuh, terbuka, berubah, (c) hubungan peneliti dengan obyek berinteraksi, penelitian dari luar dan dalam, peneliti sebagai instrumen, bersifat subyektif, judgment, (d) Seting penelitian alamiah, terkait tempat dan waktu, (e)Analisis subyektif, intuitif, rasional, (f) hasil penelitian berupa deskripsi, interpretasi, tentatif, situasional.

Maka, metode penelitian dengan pendekatan kualitatif dibedakan dalam dua macam, kualitatif interaktif dan non interaktif. Ada 5 (lima) macam metode kualitatif interaktif, yaitu metode etnegrafik, metode fenomenologis, studi kasus, teori dasar (grounded theory), dan studi kritikal. Dan dalam hal ini, jenis penelitian yang digunakan peneliti dalam penelitian kualitatif ini adalah studi kasus, yaitu suatu bentuk pendekatan yang memusatkan kajiannya pada perubahan yang terjadi dari waktu ke waktu; peneliti seolah-olah bertindak selaku saksi hidup dari perubahan itu. Studi kasus dapat digunakan secara tepat dalam banyak bidang.

\section{Kehadiran Peneliti / Instrumen Penelitian}

Dalam Penelitian kualitatif, mempunyai ciri khas yaitu tidak dapat dipisahkan dari pengamatan berperan serta, sebab peranan penelitilah yang menentukan keseluruhan skenarionya. Untuk itu, dalam penelitian ini, peneliti bertindak sebagai instrumen kunci, partisipan penuh sekaligus pengumpul data, sedangkan instrumen yang lain sebagai penunjang.

\section{Jenis Data}

Data yang diperlukan dalam penelitian ini dibagi ke dalam menjadi dua jenis yaitu antara lain;

1. Data primer yaitu data yang langsung diperoleh dari sumber atau subjek penelitian dalam bentuk verbal atau ucapan lisan dan 
perilaku subjek (narasumber penelitian) yang berkaitan dengan relevansi kompetensi (Sugiyono, 2012).

2. Adapun Data sekunder adalah data yang diambil bukan langsung dari sumber atau subjek penelitian dan digunakan untuk mendukung data primer berupa dokumen, foto, dan catatan lain yang dapat dipakai sebagai sumber data (Sugiyono, 2012).

\section{Sumber Data}

Dalam penelitian kualitatif ini, terdapat 4 (empat) sumber data yang digunakan sebagi berikut:

1. Subjek.

Subjek yaitu orang atau benda yang menjadi sumber informasi bagi masalah yang diteliti dalam suatu penelitian. Subjek dalam penelitian ini yaitu strategi bauran pemasaran dan volume penjualan Azka Toys Pamulang Tangerang Selatan.

2. Informan

Informan yaitu narasumber dalam penelitian atau orang yang menjadi sumber data bagi informasi penelitian. Informan dalam penelitian ini meliputi pemilik usaha Azka Toys berikut para tenaga pemasaran yang terlibat di dalamnya.

3. Dokumen tertulis

Dokumen merupakan bahan tertulis atau benda yang berkaitan dengan suatu peristiwa atau aktivitas tertentu. Ia bisa berupa rekaman atau dokumen tertulis seperti arsip data base surat-surat, gambar, bendabenda yang merupakan peninggalan suatu peristiwa.

Dokumen tertulis adalah sesuatu tertulis atau tercetak yang dapat memberikan informasi terkait permasalahan yang sedang diteliti dalam suatu penelitian. Dalam penelitian ini, dokumen tertulis yang digunakan adalah dokumentasi saat Walk in Interview (Wawancara Langsung) dengan pemilik usaha Azka Toys berikut para tenaga pemasaran yang terlibat di dalamnya.

4. Dokumen tidak tertulis

Dokumen tidak tertulis adalah dokumen yang tidak tertulis dan mampu memberikan informasi mengenai permasalahan yang diteliti dalam suatu penelitian. Dokumen tidak tertulis bisa berupa peristiwa atau aktivitas yang berkaitan dengan permasalahan dalam penelitian. Dari peristiwa atau kejadian, peneliti dapat mengetahui proses bagaimana sesuatu bisa terjadi secara pasti karena menyaksikan sendiri secara langsung.
Dokumentasi tidak tertulis dalam penelitian ini di peroleh peneliti melalui observasi keseharian subjek penelitian. Dalam pemilihan subjek menggunakan teknik sampling purposive sampling. Hal ini dikarena tujuan pengambilan sample bukan untuk generalisasi, melainkan untuk mencari informasi sebanyak mungkin.

\section{Metode Pengumpulan Data}

Dalam Teknik pengumpulan data merupakan langkah yang paling utama dalam penelitian, karena tujuan utama dari penelitian adalah mendapatkan data. Tanpa mengetahui teknik pengumpulan data, maka peneliti tidak akan mendapatkan data yang memenuhi standar data yang ditetapkan (Sugiyono, 2012).

Menurut S. Margono, dalam bukunya "Metodologi PenelitianPendidikan" (2003: 158181), teknik pengumpulan data yang digunakan pada metode kualitatif adalah interview (wawancara), observasi, dan dokumentasi.Teknik tersebut digunakan peneliti, karena suatu fenomena itu akan dimengerti maknanya secara baik, apabila peneliti melakukan interaksi dengan subyek penelitiandimana fenomena tersebut berlangsung.

Oleh karena itu diperlukan ketelitian dan kevalidan data untuk menentukan kualitas data yang didapatkan. Dalam hal ini, penelitian ini menggunakan beberapa teknik pengumpulan data, antara lain.

\section{a. Observasi}

Observasi sebagai teknik pengumpulan data mempunyai ciri yang psesifik bila dibandingkan dengan teknik yang lain, yaitu wawancara dan kuisioner. Kalau wawancara dan kuisioner selalu berkomunikasi dengan orang maka observasi tidak terbatas pada orang, tetapi juga obyek-obyek alam yang lain (Sugiyono, 2012). Observasi dilakukan untuk mendapatkan data tentang strategi bauran pemasaran dan volume penjualan Azka Toys Pamulang Tangerang Selatan

\section{b. Dokumentasi}

Menurut Arikunto (2006) dokumentasi adalah mencari dan mengumpulkan data mengenai hal-hal atau variabel yang berupa catatan, transkip, buku, majalah, agenda, notulen rapat, dan sebagainya. Teknik dokumentasi digunakan untuk mendapatkan data sekunder. Data ini berupa data profil Kota Tangerang Selatan dan dokumentasi saat Walk in Interview (Wawancara Langsung) dengan pemilik usaha Azka Toys berikut para tenaga pemasaran yang terlibat di dalamnya. 


\section{c. Wawancara}

Wawancara digunakan sebagai teknik pengumpulan data apabila peneliti ingin melakukan studi pendahuluan untuk menemukan permasalahan yang harus diteliti, dan juga apabila peneliti ingin mengetahui hal-hal dari responden yang lebih mendalam dan jumlah respondennya kecil atau sedikit (Sugiyono, 2012). Teknik wawancara yang digunakan dalam penelitian ini menggunakan wawancara tidak terstruktur adalah wawancara yang bebas dimana peneliti tidak menggunakan wawancara yang telah tersusun secara sistematis dan lengkap untuk pengumpulan datanya (Sugiyono, 2012).

\section{Metode Analisis Data}

Dalam Teknik analisa data berfungsi untuk mendeskripsikan teknik analisis apa yang digunakan oleh peneliti untuk menganalisa data yang telah dikumpulkan (Sanusi Anwar, 2011). Pada penelitian ini peneliti menggunakan metode analisa statistik deskriptif, yaitu suatu analisa yang dimaksudkan untuk menjelaskan data dari satu variabel yang diteliti. Pada metode ini, ukuran deskriptif yang sering digunakan untuk mendeskripsikan data hasil penelitian.

1. Pengumpulan data.

Pengumpulan data yaitu sebagai usaha dalam mengumpulkan data di lokasi penelitian dengan diawali dengan observasi, wawancara, dan dokumentasi dengan menentukan strategi mengumpulan data yang dinilai tepat dan untuk menentukan fokus serta pendalaman data pada proses pengumpulan data berikutnya.

2. Reduksi data.

Reduksi data meliputi proses seleksi, pemfokusan, pengabstrakan, transformasi data kasaryang ada di lapangan secara langsung, dan diteruskan pada waktu pengumpulan data, dengan demikian reduksi data dimulai dari peneliti memfokuskan wilayah penelitian.

3. Penyajian data.

Penyajian data yaitu sebuah rangkaian organisasi informasi yang memungkinkan penelitian dilakukan. Penyajian data diperoleh dari berbagai jenis, jaringan kerja, keterkaitan kegiatan atau pun dari tabel.

4. Penarikan kesimpulan.

Dalam menarik kesimpulan, peneliti harus memahami dan mengerti terhadap sesuatu yang diteliti langsung di lapangan dengan menyusun rangkaian dan pola-pola pengarahan secara efektif.

\section{Pengecekan Keabsahan Temuan}

Selain menganalisis data penelitian kualitatif sebagai instrumen. Keikutsertaan peneliti sangat menentukan dalam pengumpulan data agar memperoleh data yang dalam pengecekan keabsahan temuan ini penulis mengadakan interview kepada pemilik usaha Azka Toys secara langsung. Untuk menetapkan keabsahan data ini diperlukan teknik pemeriksaan.Untuk memeriksa keabsahan data mengenai "Analisis Bauran Pemasaran dalam Meningkatkan Volume Penjualan (Studi Kasus Azka Toys Pamulang Tangerang Selatan)" berdasarkan data yang sudah terkumpul, selanjutnya ditempuh beberapa teknik keabsahan. Maka dalam penelitian ini peneliti menggunakan teknik untuk mengetahui kevalidan data dengan mengadakan kegiatan sebagai berikut:

1. Triangulasi

Triangulasi adalah teknik pemeriksaan keabsahan data yang memanfaatkan sesuatu yang lain diluar data itu untuk keperluan pengecekan atau sebagai pembanding terhadap data itu, tekniknya dengan pemeriksaan sumber lainnya.

Triangulasi merupakan cara untuk melihat fenomena dari beberapa sudut, yaitu untuk membuktikan temuan dengan berbagai sumber informasi dan teknik. Misalnya hasil dari observasi dapat dicek dengan wawancara atau membaca laporan serta melihat lebih tajam hubungan antara berbagai data.

Peneliti memperoleh data mengenai strategi pemasaran hasil penjualan Azka Toys dari hasil wawancara dengan pemilik usaha Azka Toys. Dalam halinipenelititidak hanya cukup meneliti kepada satu orang saja akan tetapi peneliti perlu juga untuk mewawancarai tenaga pemasaran Azka Toys selaku pelaku aktif dalam kegiatan pemasaran, serta peneliti memerlukan beberapa dokumen-dokumen resmi untuk memastikan kebenaran kegiatan tersebut.

2. Menggunakan bahan referensi

Untuk meningkatkan kepercayaan akan kebenaran data dengan menggunakan hasil rekaman tape atau bahan dokumentasi. Peneliti data mengenai strategi pemasaran dari pemilik usaha dengan mengunakan rekaman tape dan dokumentasi. Memberikan chek bertujuan agar informasi yang diperoleh dan digunakan dalam penelitian skripsi sesuai dengan apa yang dimaksud oleh informan. Setelah mentranskrip rekaman wawancara atau mencatat hasil pengamatan atau mempelajari dokumen kemudian men- 
diskripsikan, menginterpretasikan dan memaknai data secara tertulis kemudian dikembalikan kepada sumber data untuk diperiksa kebenarannya, ditanggapi jika perlu ada pemahaman data baru, memberi chek dilakukan segera setelah ada yang masuk draf dan penelitian sesudah menjadi secara utuh.

\section{HASIL DAN PEMBAHASAN \\ Perkembangan Volume \\ Penjualan pada Azka Toys}

Perkembangan Pemasaran perlu ditinjau secara berkala, karena pemasaran memegang peranan penting dalam setiap dunia usaha karena dengan lancarnya pemasaran dengan berbagai strategi yang digunakan, seperti halnya Azka Toys menggunakan strategi bauran pemasaran $4 \mathrm{P}$ yaitu produk (product), harga (price), promosi (promotion), tempat (place), maka volume penjualan akan dapat ditingkatan, maka keuntungan akan dapat diperoleh. Begitu pula dengan Azka Toys, untuk mengetahui lancar tidaknya volume penjualan tersebut dapat dilihat dari keadaan penjualannya. Lebih jelasnya dapat dilihat pada tabel dibawah ini :

\begin{tabular}{|c|c|c|c|}
\hline \multicolumn{4}{|c}{ Tabel 1.1. Unit Penjualan } \\
\hline Tahun & $\begin{array}{c}\text { Ular Tangga } \\
\text { Sholat }\end{array}$ & Baitul Maal & Jumlah Penjualan \\
\hline 2015 & 520 & 225 & 745 \\
\hline 2016 & 712 & 197 & 909 \\
\hline 2017 & 724 & 298 & 1.022 \\
\hline 2018 & 884 & 239 & 1.123 \\
\hline Rata-rata & 971 & 332 & 1.303 \\
\hline
\end{tabular}

Dari tabel diatas terlihat bahwa terjadi peningkatan volume penjualan dari tahun 2014 sampai dengan tahun 2018, dari dua produk yang diproduksi terlihat produk Ular Tangga Sholat mendapatkan unit penjualan yang lebih stabil kenaikan penjualannya jika dibandingkan dengan produk Baitul Maal, tetapi secara total penjualan mengalami peningkatan pada setiap tahunnya. Dari peningkatan volume penjualan tersebut didapat rata-rata jumlah penjualan Azka Toys Ular Tangga Sholat Pamulang Tangerang Selatan dari tahun 2014-2018 adalah sebesar 1.020 unit, dengan penjualan terbesar pada tahun 2018 yaitu sebesar 1.303 produk mainan Islami Edukatif Azka Toys.

Hasil volume penjualan selama 5 tahun tersebut dapat menggambarkan meningkatkan penjualan dari tahun ke tahun secara menyeluruh, dengan demikian pentingnya Azka
Toys dalam memperhatikan dan mengembangkan strategi bauran pemasarannya agar volume penjualan semakin meningkat secara konsisten.

\section{Strategi Bauran \\ Pemasaran pada Azka Toys \\ 1. Srategi Produk}

Pengertian Produk adalah sebuah hasil proses produksi yang dilakukan oleh produsen atau perusahaan yang nantinya akan dijual kepada konsumen yang membutuhkan.Dilihat dari Aspek Strategi produk, keputusan mengenai jenis dan desain produk yang di produksi Permainan anak Islami Edukatif Azka Toys, memperhatikan kebutuhan dan selera konsumen, yaitu dimana anak-anak dan orangtua sangat membutuhkan produk mainan Islam edukatif guna pembelajaran agama Islam sejak usia dini melalui sebuah permainan. Dari hasil observasi lapangan Produk Azka Toys, alat-alat permainan menggunakan bahan-bahan yang berkualitas, tidak membahayakan bagi anak dan bersifat inovatif dan diferensiasi. Hal ini terlihat dari beberapa produk yang ditawarkan selalu dibuat dengan bermacam-macam jenis, ukuran dan desain yang menarik.

Semakin baik kualitas produk yang diberikan maka konsumen akan semakin berminat melakukan pembelian, Untuk itu, sudah menjadi suatu keharusan bagi Azka Toys untuk memberikan kualitas produk yang terbaik, dimana papan dan alat-alat permainannya tidak mudah rusak dan aman digunakan bagi anak. Produk Azka Toys yang dihasilkan ini mempunyai target utama konsumen yaitu anak-anak dan orangtua dengan pangsa pasar utama yaitu sekolah TK, SD dan TPA.

Maka Azka Toys dalam usahanya untuk meningkatkan volume penjualan yaitu :

a. Strategi Produk dalam Inovasi produk, yaitu :

1) Produk Ular Tangga Sholat terdapat 3 Inovasi produk yaitu produk Ular Tangga Sholat versi besar atau ekslusif, sedang dan kecil, hal tersebut dilakukan Azka Toys dalam rangka menyesuaikan produk sesuai dengan selera dan kemampuan atau daya beli konsumen.

2) Produk Baitul Maal masih dalam 1 (satu) inovasi produk, yaitu 
produk yang ditawarkan dalam versi yang produk yang berkualitas dan desain yang menarik.

b. Strategi Produk dalam Diferensiasi produk, yaitu :

Menampilkan karya anak bangsa Indonesia dari segi permainan islami edukatif yang kreatif dan inovatif yang dapat merangsang anak dalam belajar agama melalui sebuah permainan yang menyenangkan. Secara terperinci daya bedanya adalah:

1) Permainan yang bersumber dari Al Quran dan Hadits

2) Gambar-gambar pada papan permainan yang menarik untuk anak sebagai penunjang anak dalam belajar

3) Terdapat di dalamnya beberapa materi pembelajaran agama, seperti materi sholat, zakat, sedekah dan sebagainya

4) Terdapat di dalamnya beberapa pembelajaran mengenai ekonomi Islam agar anak mengetahui dan mengamalkan perekonomian sesuai dengan ajaran Islam dan Nabi Muhammad SAW

5) Membangun kedekatan anak dengan orangtua

6) Menggunakan bahan yang aman untuk anak.

7) Produk Berkualitas namun harga bersaing

Dalam diferensiasi produk Baitul Maal ini sangat berbeda dari produk lainnya, karena dalam permainan ini disajikan juga materi pembelajarannya yang bersumber dari $\mathrm{Al}$ Qur'an dan Hadits yang tidak pernah ada sebelumnya, diferensiasi produk antara lain,yaitu :

1) Mengajarkan sistem ekonomi Islam dengan cara yang menyenangkan

2) Meneladani Nabi Muhammad dalam berdagang.

3) Mengajarkan konsep berwirausaha sesuai dengan syairat Islam.

4) Membangun kedekatan anak dengan orangtua.

5) Melatih motorik dan kecerdasan anak.

6) Bersumber dari Al Qur'an dan Hadits.

7) Memudahkan anak dalam belajar materi agama, seperti hafalan surat, doa-doa sehari-hari, rukun
Islam dan materi agama lainnya,

8) Menggunakan bahan yang aman untuk anak.

9) Produk Berkualitas namun harga bersaing.

Dalam diferensiasi produk Ular

Tangga Sholat, antara lain, yaitu :

1) Mengajarkan sholat dengan cara yang menyenangkan

2) Memotivasi anak dalam menghafal bacaan sholat.

3) Memotivasi anak dalam melaksanakan sholat 5 waktu.

4) Membangun kedekatan anak dengan orangtua.

5) Melatih motorik dan kecerdasan anak.

6) Bersumber dari Al Qur'an dan Hadits.

7) Memudahkan anak dalam belajar materi sholat, seperti sholat di awal waktu, tatacara sholat dan materi sholat lainnya,

8) Menggunakan bahan yang aman untuk anak.

9) Produk Berkualitas namun harga bersaing.

c. Strategi Produk dalam Bahan dan kemasan produk, yaitu :

Kesiapan teknologi saat ini menggunakan percetakan digital printing yang dalam beberapa menit langsung tercetak dan menggunakan bahan dan kertas terbaik, karena setelah tercetak kemudian papan permainan tersebut dilapisi laminating doff, kemudian kemasan juga didesain dalam kemasan yang menarik untuk anak-anak. Namun saat ini masih menggunakan jasa percetakan melalui percetakan orang lain, karena keterbatasan biaya dalam membeli alat percetakan tersebut

\section{Strategi Harga}

Pada sebuah perusahaan, posisi harga merupakan salah satu penentu keberhasilan suatu perusahaan karena harga menentukan seberapa besar keuntungan yang akan diperoleh perusahaan dari penjualan produknya baik berupa barang maupun jasa.Adapun harga merupakan satusatunya unsur marketing mix atau bauran pemasaran yang memberikan pemasukan atau pendapatan bagi usaha. Penempatan harga dipengaruhi oleh faktor internal dan eksternal. Faktor internal tersebut meliputi tujuan perusahaan, strategi bauran pemasaran dan biaya yang dikeluarkan selama proses produksi. Faktor eksternal meliputi; 
pasar, persaingan dan unsur lingkungan lainnya. Strategi harga yang dilakukan oleh Azka Toys ini adalah dengan menempatkan harga yang terjangkau dan mempunyai variasi harga pada setiap ukuran produk, dimulai dari harga Rp10.000-Rp 80.000, penawaran variasi harga kepada konsumen diperuntukkan agar konsumen dapat membeli produk Azka Toys sesuai kemampuan atau daya beli konsumen. Hal ini membuktikan Azka Toys memperhatikan strategi harga agar dapat bersaing dengan usaha sejenis lainnya.

Harga jual Azka Toys yang ditawarkan kepada konsumen dengan berbagai variasi harga yang ditawarkan dengan tujuan menyesuaikan kemampuan atau daya beli konsumen terhadap produk Azka Toys, adapun rincian harga jual produk tersebut yaitu:

a. Ular Tangga Sholat versi kecil/murah

Biaya produksi dan desain per pcs 4.000

Biaya alat dan bahan per pcs 2.000

Biaya Administrasi dan pemasaran 1.500

Sehingga modalnya yaitu 7.500 dan dijual seharga 15.000

b. Ular Tangga Sholat versi sedang

Biaya produksi dan desain per pcs 10.000

Biaya alat dan bahan per pcs 4.000

Biaya Administrasi dan pemasaran 3.500

Sehingga modalnya yaitu 17.500 dan dijual seharga 35.000

c. Ular Tangga Sholat versi mahal/ ekslusif

Biaya produksi dan desain per pcs 20.000

Biaya alat dan bahan per pcs 8.000

Biaya Administrasi dan pemasaran 7.000

Sehingga modalnya yaitu 35.000 dan dijual seharga 70.000

d. Baitul Maal (Monopoli Islam)

Biaya produksi dan desain per pcs 33.000

Biaya alat dan bahan per pcs 17.000

Biaya Administrasi dan pemasaran 15.000

Sehingga modalnya yaitu 65.000 dan dijual seharga 130.000

Hal tersebut di atas bertujuan menyesuaikan kemampuan atau daya beli konsumen, sehingga banyaknya konsumen yang membeli dengan berbagai variasi kemampuan atau daya beli yang dimiliki kon- sumen sehingga volume penjualan Azka Toys dapat meningkat secara konsisten dan mampu bersaing perusahaan sejenis lainnya.

\section{Srategi Promosi}

Menurut ahli pemasaran, promosi diartikan sebagai upaya membujuk orang untuk menerima produk, konsep dan gagasan. Maka ditarik sebuah kesimpulan, arti promosi yaitu untuk memberitahukan, menginformasikan, menawarkan, membujuk, atau menyebarluaskan suatu produk atau jasa kepada calon konsumen dengan tujuan agar calon konsumen tersebut pada akhirnya dapat melakukan pembelian.

Dalam melakukan strategi promosi yang dilakukan oleh Azka Toys, berdasarkan hasil observasi penelitian yang dilakukan, Media promosi yang dapat digunakan pada bisnis ini antara lain:

a. Periklanan, baik berupa media cetak seperti brosur, $x$ banner maupun media online, seperti facebook, whats app, instagram dan sebagainya;

b. Promosi penjualan;

c. Pameran/ atau membuka stand di sekolah /TPA /TK; dan

d. Pemasaran langsung, penentuan media promosi yang akan digunakan didasarkan pada jenis dan bentuk produk itu sendiri.

Dari segi promosi dilihat dari volume penjualan pada tahun 2015 khusus untuk produk Baitul Maal mengalami penurunan, ini diakibatkan oleh oleh kurangnya promosi melalui media masa atau dalam bentuk lainnya sehingga masyarakat tidak mengetahui adanya produk produk Baitul Maal ini dipasaran tetapi sebaliknya untuk produk Baitul Maal mengalami peningkatan yang cukup siginifikan, karena promosi sudah dijalankan walupun hanya dalam bentuk brosur dan $X$ Banner saat pameran.

Segmentasi pasar dan permintan pasar

1. Segmen pasar : yaitu merupakan gambaran umum dari konsumen usaha kita.

Konsumen produk ini adalah anakanak dan orangtua melalui sebuah sekolah, TK, TPA, lembaga kursus, SD, MI, jamaah masjid dan sebagainya.

2. Target pasar : yaitu sasaran khusus bagi konsumen potensial dari usaha kita.

Konsumen potensial adalah TK Islam, TPA, guru, orangtua murid, pendakwah dan sebagainya. 
3. Positioning : yaitu bagaimana kita menempatkan usaha kita diantara pesaing usaha yang sejenis. Meskipun sudah ada Ular Tangga di pasaran namun produk Ular Tangga Sholat dan Baitul Maal ini memiliki diferensiasi dan nilai yang berbeda yaitu permainan Islami edukatif yang bersumber dari Al Qur'an dan Hadits dan di dalamnya terdapat beberapa pembelajaran untuk anak dapat belajar materi agama Islam.

\section{Place (Distribusi)}

Kotler menyatakan bahwa "Saluran distribusi terdiri dari seperangkat lembaga yang melakukan segala kegiatan (fungsi) yang digunakan untuk menyalurkan produk dan status pemiliknya dari produsen ke konsumen". Dari definisi diatas dapat diartikan bahwa sistem distribusi suatu barang adalah keseluruhan kegiatan atau fungsi untuk memindahkan produk disertai dengan hak pemiliknya dari produsen ke konsumen akhir atau pemakai industri.

Distribusi berkaitan dengan kemudahan memperoleh produk di pasar dan tersedia saat konsumen mencarinya. Distribusi memperlihatkan berbagai kegiatan yang dilakukan perusahaan untuk menjadikan produk atau jasa diperoleh dan tersedia bagi konsumen sasaran.

Dalam memasarkan produknya Azka Toys memilih membuka stand atau pameran di sekolah, TK ataupun TPA guna memudahkan pemasaran atau pengenalan produk kepada konsumen, namun Azka Toys juga membuka penjualan di outlet Pamulang agar masyarakat atau konsumen bisa membeli langsung produk Azka Toys, namun Azka Toysjuga perlu membuka beberapa outlet dan memperluas jaringan pemasaran. Baik pemasaran dari segi membuka banyak cabang berupa took maupun pemasaran dari segi online yang saat ini lebih dapat mendatangkan laba yang maksimal dengan biaya yang dikeluarkan untuk melakukan pemasaran lebih efektif dan efisien.

\section{Analisis Bauran Pemasaran dan Volume Penjualan Pada Azka Toys}

Sebuah persaingan usaha yang kompetitif semuanya bertujuan agar produk dapat berorientasi sesuai selera dan kebutuhan konsumen, dan konsumen pun dapat menerima produk yang kita berikan secara tepat waktu, lokasi yang tepat dan harga yang terjangkau menurut konsumen, juga promosi yang efektif dan efisien yang dapat mendatangkan keuntungan bagi sebuah perusahaan. Strategi pemasaran merupakan acuan bagi sebuah perusahaan agar mempunyai nilai positif dan unggul dalam persaingan pasar yang kompetitif,

Maka perusahaan haruslah mengetahui karakteristik pangsa pasar serta struktur pasar yang dihadapi. Hal ini dapat dicapai dengan cara pengembangan dan mencari ide dan serta gagasan terbaik dalam mengelola marketing mix yang diarahkan pada tujuan yang sesuai dengan konsep pemasaran yang diinginkan perusahaan. Konsep marketing mix pada umumnya dijadikan keunggulan bersaing dalam menghadirkan produk berkualitas sesuai dengan kebutuhan dan selera konsumen, yang merupakan dari bagiannya yaitu produk (product), harga (price), promosi (promotion), tempat (place). Keempat elemen tersebut yang perlu diperhatikan perusahaan agar dapat bersaing di pasar yang semakin kompetitif. Konsep marketing mix ini biasanya digunakan oleh perusahaan untuk menciptakan keinginan dan selera konsumen atas produk atau jasa yang ditawarkan oleh produsen atau pedagang untuk menciptakan keputusan pembelian produk yang ditawarkan oleh produsen atau pedagang serta mengukur bagaimana pengaruh dari marketing mix tersebut terhadap keputusan konsumen dalam membeli produk atau jasa yang ditawarkan.

Dengan pentingnya sebuah konsumen atau pelanggan dalam menghadirkan suksesnya suatu usaha, maka Azka Toys sebagai salah satu UKM menggunakan strategi marketing mix semaksimal mungkin dalam usahanya untuk menciptakan keputusan pembelian konsumen terhadap produk yang ditawarkan khususnya produk Azka Toys Ular Tangga Sholat yang menjadi produk utama, agar usahanya tersebut dapat diterima dengan baik dipasaran. Untuk menganalisis startegi mix yang digunakan oleh Azka Toys terhadap volume penjualan terlihat sejak tahun 2014-2018 secara keseluruhan terjadi kenaikaan volume penjualan rata-rata pada produk Ular tangga Sholat lebih baik daripada produk Baitul Maal, dikarenakan produk Ular Tangga Sholat lebih memperhatikan aspek bauran pemasaran yaitu produk (product), harga (price), promosi (promotion), tempat (place).

Disisi lain harga produk yang ditawarkan pesaing menimbulkan persaingan yang sangat ketat di antara semua perusahaan, akan tetapi saat bahan baku mengalami kenaikan beberapa usaha sejenis lainnya juga menaikkan harga jual produknya untuk menekan biaya produksi, meskipun demikian Azka Toys tidak menaikkan 
harga jualnya bahkan untuk produk Baitul Maal Azka Toys memberikan potongan harga.

Dari sisi promosi pada tahun 2015 usaha Azka Toys Pamulang sudah menganggarkan dana untuk kegiatan promosi baik dari media cetak, seperti brosur dan $x$ banner, karena sebelumnya hanya mengandalkan promosi melalui media online saja, sedangkan dari sisi distribusi usaha Azka Toys pemasarannya sudah menjangkau Jabodetabek dan sekitarnya. Keseluruhan strategi pemasaran yang dilaksanakan oleh Azka Toys melalui program bauran pemasarannya adalah untuk mencapai tujuan perusahaan khususnya sasaran pemasarannya yaitu menambah konsumen, mempertahankan pelanggan dan meningkatkan volume penjualan sehinga dengan itu usaha Azka Toys produk Ular Tangga Sholatdan Baitul Maal akan memperoleh kuntungan yang maksimal.

Untuk sisi jenis produk produk dapat dilihat produk Baitul Maal mengalami penurunan volume penjualan ditahun 2015 dan 2017, penurunan ini juga dipengaruhi oleh kebijakan marketing mix yaitu:

1. Dari segi produk usaha Azka Toys Pamulang hanya membuat produkBaitul Maal yang bahannya berkualitas tinggi, sehingga terdapat konsumen yang keberatan membeli produk Baitul Maal yang harganya cukup tinggi.

2. Demikian juga dari segi harga produk Ular Tangga Sholat lebih murah dibandingkan dengan produk Baitul Maal, mengakibatkan volume penjualan terhadap produk Baitul Maal terjadi penurunan.

3. Untuk sisi promosi juga mempengaruhi penurunan volumen penjualan produk Baitul Maal, karena promosiyang dilakukan lebih sering menggunakan media online, dimana kurangnya mengadakan pameran pada sebuah sekolah, TK atau TPA.

4. Sedangkan dari sisi tempat atau lokasi, Azka Toys terkadang tidak mempunyai lokasi berjualan yang strategis terutama saat mengadakan pameran-pameran dann juga dari sisi distribusi, produk Baitul Maal sedikit mengalami kendala saat packing, dikarenakan produk Baitul Maal mempunyai alat-alat permainan yang lebih banyak dari pada produk Ular Tangga Sholat.

\section{SIMPULAN \\ Kesimpulan}

Secara umum produk Azka Toys Ular Tangga Sholat dan Baitul Maal ini mengalami perkembangan penjualan yang baik dari tahun ke tahun jika diakumulasi kedua produk yang dihasilkan oleh Azka Toys, dimana pada tahun 2018 terjadi peningkatan volume penjualan yang sangat signifikan. Dari peningkatan volume penjualan tersebut didapat rata-rata jumlah penjualan Azka ToysUlar Tangga Sholat Pamulang Tangerang Selatan dari tahun 20142018 adalah sebesar 1.020,4 unit, dengan penjualan terbesar pada tahun 2018 yaitu sebesar 1.303 produk mainan Islami Edukatif Azka Toys.

Strategi bauran Pemasaran Marketing Mix yang dijalan Strategi oleh Azka Toys terjadi dari, Strategi produk dimana keputusan mengenai jenis dan desain produk yang di produksi Permainan anak Islami Edukatif Azka Toys, memperhatikan kebutuhan dan selera konsumen, Azka Toys juga selalu menawarkan produk dengan berbagai inovasi, kreativisasi, kemasan menarik dan diferensiasi atau ciri khas yang menarik yaitu sebuah permainan yang menawarkan edukasi pembelajaran agama Islam di dalamnya.

Kemudian Strategi Harga, harga merupakan satu-satunya unsur marketing mix yang menghadirkan pendapatan atau laba bagi sebuah perusahaan. Penempatan harga dipengaruhi oleh faktor internal dan eksternal. Faktor internal tersebut meliputi tujuan perusahaan, strategi bauran pemasaran dan biaya yag dikeluarkan selama proses produksi. Faktor eksternal meliputi; pasar, persaingan dan unsur lingkungan lainnya. Strategi harga yang dilakukan oleh Azka Toys ini adalah dengan menempatkan harga yang terjangkau dan mempunyai variasi harga pada setiap ukuran produk, dimulai dari harga Rp10.000-Rp 80.000, penawaran variasi harga kepada konsumen diperuntukkan agar konsumen dapat membeli produk Azka Toys sesuai kemampuan atau daya beli konsumen.

Disamping ada Srategi Promosi dalam melakukan strategi promosi Azka Toys, berdasarkan hasil observasi penelitian yang dilakukan, promosi untuk produk Baitul Maal dilakukan dengan berbagai macam cara media promosi, baik media cetak maupun secara online, melalui pameran ataupun juga melakukan pemasaran langsung, karena Azka Toys pada prinsipnya selalu berusaha memasarkan produknya dengan berbagai cara untuk meningkatkan penjualan.

Sedangkan Strategi Saluran Promosi dari hasil wawancara dengan pemilik Azka Toys, bahwa keberhasilan utama Azka Toys terletak banyaknya usaha Azka Toys dalam membuka pameran atau stand bazar di sekolah, TK 
dan TPA, sehingga saat pameran dilakukan, konsumen langsung secara spontan membeli dengan jumlah banyak, karena konsumen langsung dapat melihat produk Azka Toys dengan berbagai variasi produk, inovasi dan kemasan yang menarik.

\section{Saran}

Saran untuk Azka Toys dalam rangka meningkatkan volume penjualan secara konsisten, antara lain yaitu :

1. Dari segi strategi produk usaha, maka Azka Toys Pamulang perlu membuat produk terutama produk Baitul Maal lebih bervariasi desain, kemasan dan bahan yang sesuai kebutuhan dan selera konsumen, karena setiap konsumen pasti mempunyai selera dan model yang diinginkan berbedabeda.

2. Dari segi harga, perlunya Azka Toys menyesuaikan harga sesuai dengan kemampuan konsumen dalam membelinya terutama dalam produk Baitul Maal yang masih memproduksi hanya 1 (satu) produk saja yaitu menawarkan harga jual yang tinggi, karena tidak semua konsumen mampu membeli produk mainan dengn harga yang tinggi atau mahal.

3. Dalam sisi promosi, Azka Toys harus lebih sering mengadakan pameran pada sebuah sekolah, TK atau TPA, karena setiap pameran yang diikuti, Azka Toys dapat memperoleh laba yang maksimal dan penjualan yang terbilang efektif serta Azka Toys juga harus dapat menseleksi lagi tenaga pemasaran yang lebih berpengalaman dan kompeten di bidang pemasaran agar volume penjualan mengalami peningkatan yang konsisten pada setiap tahunnya.

4. Sedangkan dari segi tempat atau lokasi, Azka Toys harus mempunyai lokasi berjualan yang strategis terutama saat mengadakan pameran-pameran, dimana lokasi stand-nya harus berada di lokasi terdepan yang sering dilewati konsumen, agar mudah terlihat oleh konsumen dan konsumen dapat mudah membelinya. Lokasi usaha yang dimiliki Azka Toys juga harus perlu segera membuka cabang baik cabang toko maupun memperluasi jaringan dalam bentuk pemasaran online, jika seringnya online dilakukan oleh Azka Toys, maka artinya lokasi usaha yang dimiliki Azka Toys terbilang banyak dan dimana saja, yang berarti volume penjualan akan lebih meningkat secara konsisten.

\section{DAFTAR PUSTAKA}

Alma, Buchari. 2007.Manajemen Pemasaran \& Pemasaran Jasa. Bandung. CV. Alfabeta.

Anggora, M. Toha,dkk., 2007. Metode Penelitian. Jakarta. Universitas Terbuka.

Arikunto, Suharsimi. 2006. Prosedur Penelitian. Jakarta. Rineka Cipta.

Cooper, Donald R., dan Pamela, S. Schindler. 2006. Metode Riset Bisnis. Volume 1. Jakarta. PT Media Global Edikasi.

Effendi. 2010. Asas Manajemen Pemasaran. Jakarta. Gramedia Pustaka Utama.

Kotler, Philip, AB. Susanto. 2000. Manajemen Pemasaran di Indonesia. Buku 2, Jakarta. Salemba Empat.

Kotler, Philip. 2009. Manajemen Pemasaran. Jilid Kedua. Edisi Tiga Belas. Jakarta. Erlangga.

Kotler, Philip dan Gary Amstrong. 2008. Dasar-dasar Pemasaran. Jilid 1. Jakarta. PT Indeks.

Kotler, Philip, dkk. 2004. Manajemen Pemasaran dengan pemasaran efektikf dan Pofitable. Cetakan Kedua. Jakarta. Gramedia Pusat Utama.

Kotler dan Keller. 2009. Manajemen Pemasaran. Edisi 12 Jilid 1. Jakarta. PT Indeks.

Lupiyoadi. 2006. Manajemen Pemasaran Jasa. Edisi Kedua. Jakarta. Salemba Empat.

Machfoedz. 2010. Komunikasi Pemasaran Modern. Yogyakarta. CakraIlmu.

Margono,S. 2003. Metodologi Penelitian Pendidikan. Jakarta. Rineka Cipta.

Mulyong, Lexy J. 2002. Metodologi Penelitian Kualitatif. Bandung. PT Remaja Rosdakarya.

Ridwan. 2013. Inovasi Pembelajaran. Jakarta. Bumi Aksara

Stanton. 2005. Prinsip Pemasaran. Cetakan Ketujuh. Jakarta. Penerbit Erlangga.

Sugiyono. 2012. Metode Penelitian Kuantitatif, Kualitatif dan R\&D. Bandung. Alfabeta.

Sukmadinata, Nana Syaodih, 2007. Metode Penelitian Pendidikan. Bandung. Remaja Rosdakarya.

Sunjoyo dkk... 2013. Aplikasi SPSS untuk SMART Riset. Bandung, Alfabeta.

Supardi. 2013. Aplikasi Statistika Dalam Penelitian. Jakarta. Change Publication.

Suparyanto, RW dan Rosad.2015. Manajemen Pemasaran. Bogor. IN MEDIA- Anggota IKAPI.

Swastha, Basu, DH, Irawan MBA. 2005. Manajemen Pemasaran Modern. Yogyakarta. Liberty

Tjiptono, Fandydan Gregorius Chandra. 2005. Manajemen Kualitas Jasa. Yogyakarta. ANDI. 
Tjiptono. 2007. Bauran Pemasaran Jasa. Jawa Timur. Bayu Media.

, 2008. Strategi Pemasaran. Edisi Pertama. Yogyakarta. Andi.

Umar. 2008. Metode Penelitian untuk Skripsi dan Tesis Bisnis. Jakarta. PT Raja Grafindo Persada.

Widiyanto, Mikha Agus. 2013. Statistika Terapan. Jakarta. PT Elex Media Komputindo. 